\title{
PELATIHAN PENGGUNAAN PERANGKAT PEMBELAJARAN ONLINE BAGI GURU-GURU MAN DI KABUPATEN JOMBANG
}

\author{
Mariana Ulfah Hoesny, Yani Ratnawati, Lia Agustina, Aly Imron \\ Politeknik Negeri Malang \\ marianah.ulfah@polinema.ac.id, yani.ratnawati@polinema.ac.id, lia.agustina@polinema.ac.id, \\ aly.imron@polinema.ac.id
}

\begin{abstract}
The use of online learning tools has been urgent due to covid-19 pandemic. The tools have become primary needs in teaching and learning especially in English teaching. This program aimed at conducting training and workshop to use online learning tools for English teachers of Madrasah Aliyah in Jombang regency, East Java. The workshop was done via zoom meeting because offline meeting was not allowed during the pandemic. The first topic presented in the established workshop was about how technology transform education. The next topics were more specific ones; they were about utilizing online learning tools and project based learning to teach the four skills in English. There were 148 participants attending the workshop. According to te participants, the most interesting topics during the workshop were about the use of story jumper to teach writing and how to make podcast to teach speaking.
\end{abstract}

Keywords: online learning, technology, english teaching

\section{ANALISIS SITUASI}

Kemajuan teknologi digital yang terjadi pada era revolusi industri 4.0 telah memicu bermunculannya berbagai perangkat teknologi digital. Kemajuan teknologi ini mewarnai dalam berbagai bidang, termasuk bidang pendidikan. Pada awal kemunculannya, teknologi digital belum begitu banyak dimanfaatkan dalam pendidikan. Selain memerlukan keterampilan, ketersediaan internet juga menjadi penghambat. Tetapi, sejalan dengan tuntutan jaman, serta terjadinya pandemi penggunaan perangkat online dalam pendidikan menjadi keharusan.

Perangkat online dalam pembelajaran telah banyak diciptakan, tetapi pemanfaatannya dalam pembelajaran masih terbatas. Hal ini dapat disebabkan oleh masih terbatasnya keterampilan dalam menggunakan perangkat tersebut dalam pembelajaran. Selain itu biaya yang diperlukan dalam penggunaan perangkat online ini juga dinilai menjadi penghambat. Seperti yang telah diketahui, bahwa untuk berselancar di internet dibutuhkan paket data dengan harga yang bervariasi, sesuai dengan provider seluler yang menyediakan paket data tersebut. Terjadinya pandemi covid-19 menuntut proses belajar mengajar dimediasi oleh perangkat online, sehingga guru dan siswa harus belajar tentang bagaimana menggunakannya.

Kabupaten Jombang adalah daerah yang terletak di Jawa Timur, tepatnya di bagian tengah propinsi Jawa Timur. Kota yang terkenal sebagai kota santri ini memiliki banyak pondok pesantren yang cukup populer. Seperti misalnya Tambakberas, Tebuireng, Denanyar, dan Darul Ulum. Kota kabupaten yang berbatasan dengan kabupaten Lamongan, Mojokerto, Kediri, Malang dan Nganjuk ini memiliki luas wilayah 1.159,50 Km2 (RPI2JM, 2018). Saat ini kabupaten Jombang dipimpin oleh Bupati $\mathrm{Hj}$. Mundjidah Wahab dan wakil bupati Sumrambah.

Sebagai kota santri Jombang memiliki beberapa madrasah aliyah, atau yang setingkat dengan sekolah menengah atas. 
MAN 5 Jombang adalah salah satunya. Sekolah ini terletak di Godong, Genukwatu, Ngoro. Dulunya MAN 5 bernama Madrasah Aliyah Swasta Bahrul Ulum yang berdiri sejak tahun 1974. Sekolah ini menjadi Madrasah Aliyah Negeri 5 Jombang sejak tahun 2018. Sekolah berbasis agama ini memiliki visi Terbentuknya generasi Ilman Fil Hakim (berilmu, beriman, terampil, lingkungan hidup sehat dan akhlaqul karim) ((MAN 5 JOMBANG, n.d.)

Sebagai sebuah sekolah yang terletak di kabupaten, MAN 5 Jombang memerlukan pelatihan khususnya untuk meningkatkan kualitas guru. Terjadinya pandemi yang menuntut pelaksanaan pembelajaran secara daring, merupakan tantantangan tersendiri bagi para guru. Banyaknya perangkat daring serta tuntutan untuk menguasainya membuat para guru harus bekerja ekstra keras supaya memenuhi tuntutan tersebut. Dengan demikian pelatihan penggunaan perangkat daring sangat dibutuhkan.

Pelatihan penggunaan perangkat online ini juga dapat menjadi sarana untuk memperbaiki kualitas guru, yang pada akhirnya akan memperbaiki kualitas proses belajar mengajar. Dalam UU no 14 Tahun 2005 pasal 7 (Mustofa, 2007) diamanatkan bahwa bahwa pemberdayaan profesi guru diselenggarakan melalui pengembangan diri yang dilakukan secara demokratis, berkeadilan, tidak diskriminatif, dan berkelanjutan dengan menjunjung tinggi hak asasi manusia, nilai keagamaan, nilai kultural, kemajemukan bangsa, dan kode etik profesi. Disamping itu menurut pasal 20, dalam melaksanakan tugas keprofesionalan, guru berkewajiban meningkatkan dan mengembangkan kualifikasi akademik dan kompetensi secara berkelanjutan sejalan dengan perkembangan ilmu pengetahuan, teknologi, dan seni. Pelatihan yang direncakan dalam kegiatan PKM ini sesuai dengan cita-cita UU no 14 tahun 2005 tersebut.
Selain terkait dengan pandemi, pelatihan penggunaan perangkat online juga dibutuhkan dalam rangka pengembangan profesionalisme guru. Dalam era digital di Revolusi Industri 4.0 ini, diperlukan profil baru bagi profesi guru. Definisi profesi guru dan tanggung jawabnya sudah bergeser menjadi fasilitator serta actor yang bertanggung jawab dalam pengembangan kepribadian siswa dalam konteks dunia digital(Serdenciuc, 2016). Sehubungan dengan peranan baru ini, sudah selayaknya guru menguasai teknologi yang berkembang pesat. Kemampuan ini menjadi primer karena guru akan menghadapi pebelajar yang merupakan digital natives.

Terkait dengan kebutuhan tersebut pengembangan profesionalisme guru dalam bentuk pelatihan, khususnya pelatihan penggunaan perangkat digital akan menjadi poin penting. Darling (2006) dalam(Andriani, 2010) menyatakan bahwa tuntutan bagi guru di abad 21 semakin meningkat. Mereka dituntut tidak hanya mampu mengajar dan mengelola kegiatan kelas dengan efektif, namun juga dituntut untuk mampu membangun hubungan yang efektif dengan siswa dan komunitas sekolah, menggunakan teknologi untuk mendukung peningkatan mutu pengajaran, serta melakukan refleksi dan perbaikan praktek pembelajarannya secara terus menerus.

Selain itu guru di abad 21 juga diharapkan untuk memiliki orientasi pada teknologi karena mereka pun akan menjadi fasilitator serta mendorong pebelajar untuk bersentuhan dengan teknologi dalam kegiatan pembelajaran(Amin, 2016). Dengan orientasi yang baru ini, guru secara eksplisit diminta untuk mengakomodasi kebutuhan yang bermacam-macam di dalam kelas. Serta menyajikan kesempatan yang luas bagi siswa untuk belajar dengan dinamis. Guru tidak lagi berperan seperti sumber ilmu pengetahuan yang menjadi pusat kegiatan dalam aktivitas pembelajaran. Tetapi juga mampu memberikan peran yang seimbang 
pada pebelajar untuk terlibat aktif dalam pembelajaran. Hal tersebut menyangkut paradigm students-centered learning yang marak digaungkan. Paradigma studentscentered learning tersebut selayaknya dikombinasikan dengan perangkat online yang sekarang banyak tersedia dengan adanya perkembangan teknologi yang pesat. Pelatihan yang diselenggarakan dalam kegiatan Pengabdian pada Masyarakat ini ditujukan untuk mendukung terwujudnya tugas guru tersebut.

\section{METODE PELAKSANAAN}

Pengabdian kepada masyarakat ini dilaksanakan melalui beberapa tahap karena seminar dan pelatihan yang akan diadakan harus direncanakan. Tahap pertama adalah perencanaan. Tahap ini diperlukan untuk mengetahui berapa jumlah partisipan, bagaimana metode pelaksanaan, serta referensi yang nanti dapat diberikan kepada MA yang dituju untuk menambah pengetahuan tentang penggunaan perangkat online. Tahap kedua adalah adalah melakukan survei ke MA yang dituju di kabupaten Jombang. Survei ini dilakukan untuk memastikan jumlah peserta, dan kesesuaian materi yang akan disampaikan pada saat seminar dan workshop. Selain itu survei juga dilakukan sebagai langkah perkenalan tim PKM Polinema dan program yang akan diselenggarakan.

Tahap berikutnya adalah pelaksanaan. Pelaksanaan akan dilakukan dalam dua kali tatap maya/tatap muka jika dimungkinkan. Bagian pertama adalah pelaksanaan seminar. Dalam seminar materi tentang perangkat online dan macamnya, bagaimana menggunakan perangkat tersebut secara efektif serta strategi pembelajaran yang dapat diterapkan sejalan dengan penggunaan perangkat online tersebut akan disampaikan. Bagian kedua dari tahap pelaksanaan adalah pelatihan yang akan diisi dengan praktek penggunaan perangkat online oleh peserta. Narasumber sekaligus mentor akan membimbing peserta untuk langsung mengoperasikan perangkat online dan melakukan praktek mengajar menggunaakan perangkat tersebut. Metode pelaksanaan dapat divisualkan sebagai berikut;

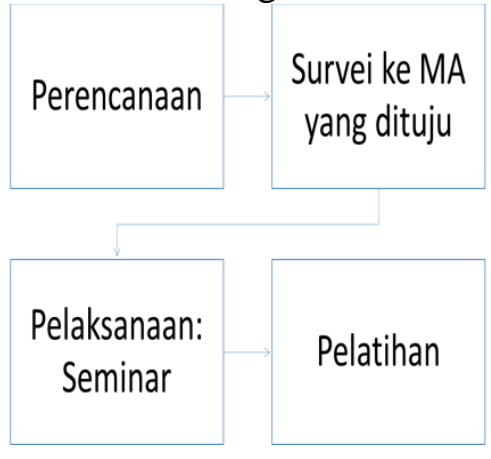

Gambar 1. Metode Pelaksanaan

\section{HASIL DAN PEMBAHASAN}

Kegiatan PPM ini telah dilaksanakan pada tanggal 26 Juni 2021. Sebanyak 180 peserta hadir dalam acara pelatihan penggunaan perangkat pembelajaran online. Jumlah pendaftar adalah sekitar 200 peserta yang berasal dari anggota Musyawarah Guru Mata Pelajaran MA Propinsi Jawa Timur. Berdasarkan hasil kegiatan tersebut diperoleh beberapa hasil sebagai berikut;

1. Penggunaan Perangkat Pembelajaran Online Sebagai Bentuk Peningkatan Profesionalisme Guru.

Menggunakan perangkat online bukan lagi keharusan bagi guru. Hal tersebut telah menjadi kebutuhan. Khususnya pada masa pandemi, di mana pembelajaran tatap muka dimediasi oleh perangkat online. Perubahan yang cepat akibat kemajuan teknologi menjadikan penguasaan teknologi hal yang vital bagi guru. Perubahan-perubahan dalam dunia pendidikan khususnya yang terkait dengan teknologi harus dikuasai(Rachida Labbas \& El Shaban, 2013).

Kendala terkait teknologi banyak dihadapi oleh guru. Kendala tersebut antara lain; penguasaan teknologi yang membutuhkan waktu dan energi, banyaknya aplikasi yang tersedia untuk 
mendukung pembelajaran sehingga guru memerlukan pengetahuan tertentu untuk menentukan aplikasi yang akan digunakan. Selain itu beragamnya istilah dalam pembelajaran online, serta bagaimana menggunakan perangkat tersebut dengan kreatif sehingga dapat mencapai target pembelajaran yang diinginkan.

2. Peranan Teknologi dalam Mentransformasikan Pendidikan

Dalam kaitannya dengan peranan teknologi, terdapat beberapa hal yang disampaikan yaitu;

a. Dampak teknologi dalam belajar dan mengajar.

b. Belajar dan mengajar sebelum dan sesudah online learning.

c. Bagaimana cara merancang virtual classroom.

d. Peran interaktif teknologi dalam mengajar.

e. Keuntungan interaktif teknologi.

Dalam kaitannya dengan dampak teknologi dalam mengajar, terdapat hal positif yang dapat diambil. Sejak teknologi menjadi hal yang vital dalam belajar mengajar, pendidikan 24 jam menjadi hal yang tidak mustahil lagi. Selain itu tingkat keterlibatan pebelajar dapat ditingkatkan dengan hadirnya beragam perangkat yang dapat mendorong students' engagement. Pengetahuan juga meningkat pesat karena sumber informasi dan pengetahuan yang melimpah tersedia serta dapat diakses dengan gratis. (Smaldino, 2015)

Sebelum pembelajaran online diimplementasikan, pembelajaran bersifat teacher-centered dan terbatas dalam konteks ruang dan waktu. Tetapi, dengan hadirnya pembelajaran online, penerapan pembelajaran kolaboratif yang lebih menarik dan menantang dapat diterapkan.

Kelas virtual yang dapat mengakomodir pembelajaran tanpa tatap muka langsungdilaksanakan melalui lima langkah yaitu; memilih learning management system, mengkaji semua bahan online, mempersiapkan linimasa dan aplikasi untuk berkomunikasi, memilih platform untuk streaming yang aman, serta memilih aplikasi yang mendukung kolaborasi.

Pembelajaran memiliki beberapa keuntungan baik bagi guru maupun siswa. Keuntungan pertama adalah guru dapat menciptakan pembelajaran dengan bermacam-macam media. Hal ini karena perangkat online menyediakan banyak ragam baik aplikasi, web, maupun platform yang dapat dimanfaatkan untuk pembelajaran. selanjutnya, pembelajaran online memungkinkan guru untuk memberika umpan balik lebih cepat. Ini disebabkan oleh aplikasi atau platform dapat diakses melalui smartphone, sehingga umpan balik dapat diberikan kapan saja, tidak terbatasi oleh ruang dan waktu. Keuntungan ketiga adalah guru dapat menerapkan strategi pembelajaran yang fleksibel, sehingga siswa dengan gaya belajar berbeda dapat dengan mudah beradaptasi.

Pada sisi siswa terdapat beberapa keuntungan dari online learning seperti; perangkat online dapat meningkatkan engagement atau keterlibatan siswa dalam kegiatan pembelajaran. yang kedua, siswa dapat memandu sendiri bagaimana dia akan belajar. Pembelajaran dapat disesuaikan dengan kecepatan yang dapat diadaptasi oleh siswa. Yang terakhir adalah pembelajaran menjadi lebih menyenangkan dan melibatkan partisipasi aktif siswa.

Dalam perkembangan selanjutnya, online learning akan mengalami peningkatan pesat. Hal ini berkaitan dengan ketersediaan sumber dan kemudahan akses pembelajaran online akibat teknologi serta kehadiran internet. Ini berarti akan hadir kelas 
online yang artinya setiap pebelajar akan menjadi bagian dari pembelajaran digital. Pasar global untuk kursus praktis dan sertifikat keahlian. Perbaikan kualitas blended learning. Meningkatnya tuntutan untuk program yang berbasis keterampilan. Investasi yang lebih besar pada teknologi interaktif untuk mengatasi perpecahan digital.

3. Pemanfaatan Perangkat Online dan Pembelajaran Proyek untuk Pembelajaran Bahasa Inggris

Penggunaan perangkat online bukan saja sebuah kebutuhan, tetapi juga kewajiban. Guru di era ini tidak dapat menggunakan cara lama untuk mengajar pebelajar yang lahir dan tumbuh di era baru. Dengan demikian, penyesuaianpenyesuain perlu dilakukan.

Pemanfaatan perangkat online yang dipadukan dengan strategi pembelajaran yang berbasis pada pebelajar mutlak diperlukan. Hal ini khususnya penting untuk pembelajaran bahasa Inggris. (Zhou \& Wei, 2018) menyatakan bahwa perubahan yang cepat di abad 21 mengubah lanskap pembelajaran bahasa asing, khususnya Bahasa Inggris. (Boonyopakorn, 2016) menambahkan bahwa internet berperan sebagai perangkat yang efisien untuk meningkatkan pemerolehan bahasa dalam pembelajaran Bahasa Inggris.

Sehubungan dengan pembelajaran online, terdapat beberapa prinsip yang perlu diperhatikan (Spector, 2016) yaitu;

a. Integrasi teknologi dalam pendidikan sebaiknya memperbaiki belajar, performansi dan pembelajaran.

b. Stakeholders sebaiknya diberi informasi dan pengguna utama (guru dan pelatih) harus dilatih dengan baik dalam hal penggunaan teknologi baru.

c. Melatih guru dan pelatih tentang bagaimana menggunakan teknologi untuk tujuan penggunaan dalam bidang pedagogi yang efektif adalah hal yang penting.

d. Pelatihan bagi pengguna tentang sebuah teknologi baru adalah hal yang sangat penting.

e. Dukungan yang baik terhadap teknologi baru harus diberikan sebelum peluncuran teknologi tersebut.

f. Representasi yang sistematis dari peranan dan penggunaan sebuah teknologi baru harus dibangun sebelum implementasi.

g. Biaya teknologi jangan sampai melebihi manfaatnya.

h. Jangan berharap bahwa teknologi akan secepatnya atau secara ajaib mengubah belajar dan pembelajaran. Dalam kaitannya dengan perangkat online dalam pembelajaran Bahasa Inggris terdapat beberapa aplikasi maupun platform yang dapat digunakan. Contohnya adalah sebagai berikut;

Untuk kegiatan pembelajaran dalam kelas menulis story jumper, postermywall, canva, grammarly dan writing platform dapat digunakan. Aplikasi tersebut dapat digunakan secara gratis maupun berbayar. Selain itu canva, grammarly, aplikasi menulis dapat diakses melalui smartphone sehingga memudahkan pebelajar. Untuk story jumper dan postermywall hanya dapat diakses melalui web. Penggunaan story jumper sangat menarik dan mendorong pebelajar untuk terlibat aktif. Aplikasi ini dapat digunakan oleh pebelajar untuk menulis cerita maupun paragraf dengan bermacam jenis untuk melatih ketrampilan menulis. Story jumper tidak hanya menyediakan jenis font serta ukurannya, tetapi juga beragam gambar dan audio yang dapat membuat cerita serta tulisan yang disajikan menjadi lebih hidup. 
Penggunaan story jumper dapat dikombinasikan dengan penerapan pembelajaran proyek. Sehingga manfaat yang dapat diambil oleh guru maupun pebelajar bukan hanya peningkatan keterampilan menulis tetapi juga keterampilan non akademik seperti keterampilan berkolaborasi, berkreasi dan berkomunikasi.

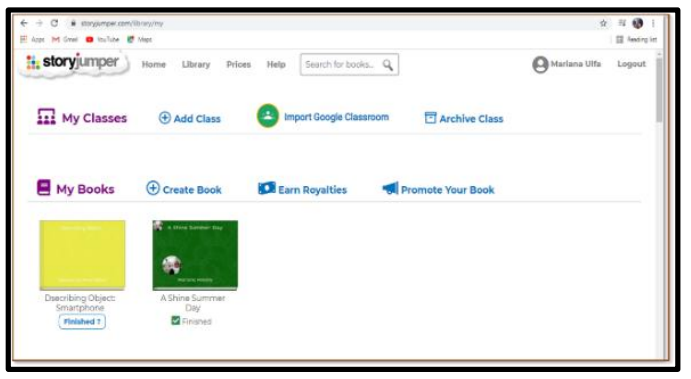

Gambar 2. Tampilan Halaman Awal Story Jumper

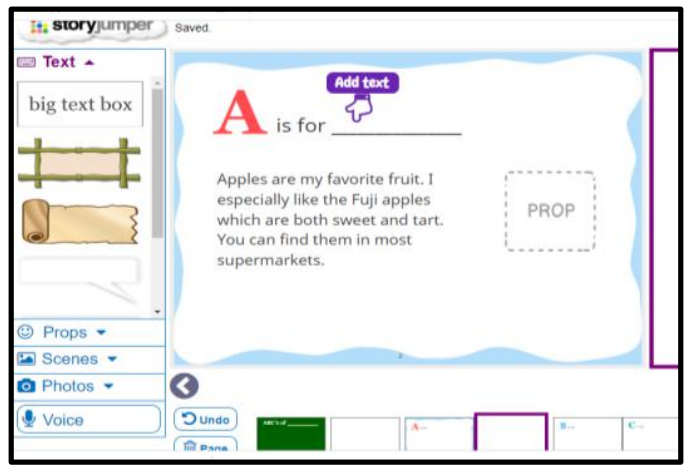

Gambar 3. Halaman Untuk Menginput Tulisan pada Story Jumper

Untuk pembelajaran keterampilan berbicara terdapat beberapa aplikasi yang dapat digunakan dalam mendukung aktivitas pembelajaran. beberapa contohnya adalah voice spice dan anchor.fm. voice spice adalah aplikasi yang dapat digunakan untuk merekam suara dan melakukan bermacam-macam modifikasi pada suara. Sedangkan anchor.fm adalah aplikasi untuk membuat podcast. Pebelajar dapat diarahkan untuk membuat sebuah proyek yang produk akhirnya adalah podcast. Seperti yang diketahui, podcast kembali populer akhir- akhir ini. Dengan membuat podcast pebelajar tidak hanya belajar berbicara tetapi juga mempraktekkan keterampilan berbicara dalam konteks yang lebih bermakna. Artinya mereka tidak merasa belajar karena yang dilakukan tujuannya sesuai dengan apa yang saat ini terjadi di dunia nyata. Dengan aplikasi tersebut diharapkan students' engagement dapat lebih meningkat sehingga keterampilan berbicara juga meningkat.

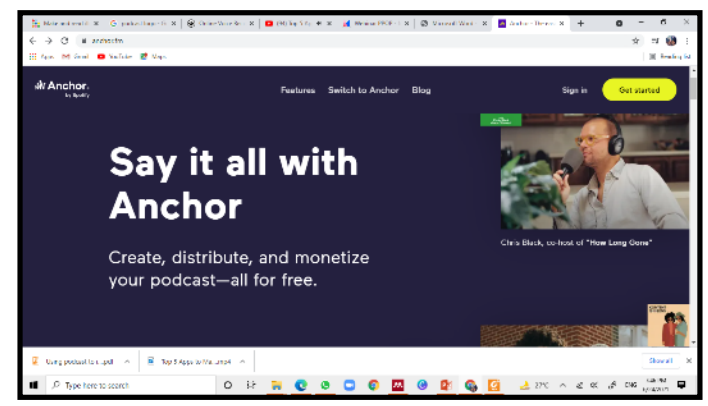

Gambar 4. Halaman Awal anchor.fm.

Selain aplikasi yang telah disebutkan, pembelajaran online menyajikan bermacam-macam sumber belajar yang dapat diakses dengan mudah. Seperti misalnya google podcast yang dapat digunakan untuk pembelajaran listening dan speaking. Kemudian, terdapat juga web seperti bbc learning English yang menyajikan beragam bacaan serta pertanyaan untuk pemahaman. Ello.org juga sumber web lain yang memberikan dialog dalam bentuk script serta audio. sehingga pebelajar dapat belajar intonasi, fluency dan accuracy khususnya dalam sebuah dialog.

Selain itu breakingnewsenglish dapat dipertimbangkan sebagai salah satu sumber bacaan yang menyediakan juga audio, latihan tata bahasa, latihan menulis, latihan berbicara dan rangkaian kosakata. Semua sumber tersebut dapat diakses tanpa biaya dan guru dapat menggunakaan dengan kreatif untuk pembelajaran Bahasa Inggris. 


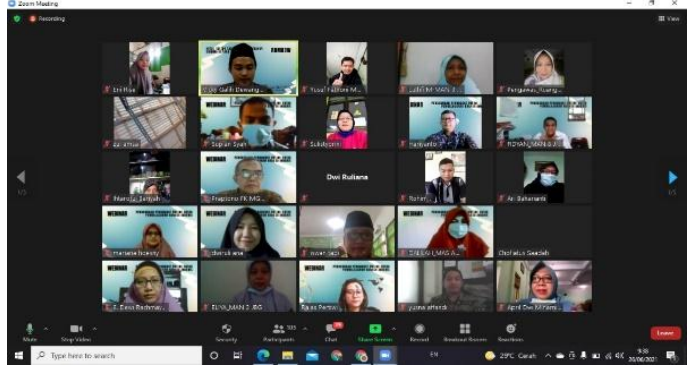

Gambar 5. Foto Pelaksanaan

\section{KESIMPULAN}

Dari paparan kegiatan Pengabdian pada Masyarakat yang telah dilaksanakan dapat disimpulkan bahwa penguasaan perangkat online dalam pembelajaran telah menjadi hal yang tidak dapat dihindarkan bagi guru. Hal tersebut bukan lagi kebutuhan sekunder melainkan telah bergeser menjadi kebutuhan primer. Dalam penggunaan perangkat online ini terdapat beberapa kesulitan yang sering dialami guru. Yang pertama adalah perangkat online tersebut memerlukan pelatihan dalam penguasaannya. Selain itu terdapat banyak perangkat online yang tersedia, sehingga membutuhkan ketelitian dalam memilihnya. Penggunaan perangkat online yang tepat dan kreatif juga diperlukan sehingga perangkat canggih tersebut dapat mendorong perbaikan hasil belajar, bukan sebaliknya. Kendala lain adalah ketersediaan internet. Pada beberapa daerah tertentu internet masih menjadi hal yang mewah. Untuk penyediaannya dibutuhkan biaya serta usaha yang tidak mudah. Kendala lain adalah perangkat untuk mengakses perangkat online tersebut, seperti smartphone dan computer. Guru dan siswa yang lokasinya jauh dari pusat kota kemungkinan besar masih mengalami kendala dalam hal penyediaan perangkat tersebut. Selain itu tingkat social ekonomi juga berpengaruh pada penyediaan perangkat.

\section{Ucapan Terima Kasih}

Ucapaan terima kasih ditujukan kepada MGMP MA Propinsi Jawa Timur beserta jajaran pengurus yang telah mendukung pelaksanaan kegiatan ini.

\section{DAFTAR PUSTAKA}

Amin, J. N. (2016). Redefining the Role of Teachers in the Digital Era. The International Journal of Indian Psychology ISSN, 3(3), 2348-5396. https://doi.org/18.01.101/20160303 @

Andriani, D. E. (2010). Mengembangkan Profesionalitas Guru Abad 21 Melalui Program Pembimbingan Yang Efektif. Manajemen Pendidikan, 6(02), 78-92. https://journal.uny.ac.id/index.php/jmp/ article/viewFile/3639/3112

Boonyopakorn, J. (2016). Technology enhanced language learning on English communication for EFL learners. IMSCI 2016 - 10th International MultiConference on Society, Cybernetics and Informatics, Proceedings, Imsci, 200205.

MAN 5 JOMBANG. (n.d.). https://man5jombang.sch.id/

Mustofa. (2007). Upaya Pengembangan Profesionalisme Guru di Indonesia. Jurnal Ekonomi \& Pendidikan, 4(November), 47-62.

Rachida Labbas, by, \& El Shaban, A. (2013). Teacher Development in the Digital Age. Teaching English with Technology, 13(3), 53-64. https://doi.org/10.1097/NNA.00000000 00000021

RPI2JM. (2018). Rencana Terpadu Dan Program Investasi Infrastruktur Jangka Menengah Kabupaten Jombang (pp. 118).

http://sippa.ciptakarya.pu.go.id/sippa_o nline//ws_file/dokumen/rpi2jm/DOCRP IJM_725a658697_BAB IIBab 2 Profil.pdf

Serdenciuc, N. L. (2016). Being a Teacher in a Digital Era. International Journal of Social and Educational Innovation, 3(5), 73-80.

Smaldino, S. E. et. al. (2015). Instructional Technology and Media for Learning (11th Editi). Pearson Education.

Spector, J. M. (2016). Foundations of Educational Technology (2nd Editio). 
Routledge.

Zhou, Y., \& Wei, M. (2018). Strategies in technology-enhanced language learning. Studies in Second Language Learning and Teaching, 8(2 Special Issue), 471495.

https://doi.org/10.14746/ssllt.2018.8.213 